\title{
A new species of Anisopteromalus Ruschka (Hymenoptera: Chalcidoidea: Pteromalidae) from Sri Lanka
}

\section{P.M. Sureshan}

Scientist C, Zoological Survey of India, Western Ghat Regional Centre, Jaferkhan Colony, Eranhipalalm P.O., Kozhikode, Kerala 673006, India

Email:pmsuresh43@yahoo.com

\begin{abstract}
A new species of Anisopteromalus Ruschka, A. ceylonensis sp. nov. (Hymenoptera: Pteromalidae) is described from Sri Lanka. The affinities of the new species with the related species are discussed.
\end{abstract}

Keywords: Anisopteromalus, Chalcidoidea, Hymenoptera, new species, Pteromalidae, Sri Lanka.

Anisopteromalus Ruschka (Pteromalidae: Pteromalinae) is an economically important genus, members of which are parasites of mainly small beetles and moths associated with stored products (cereals and pulses). Anisopteromalus is characterized by having antenna with three anelli in female and two in male, gaster with hind margin of T1 produced in to sub angular lobes often collapsed and strongly narrowed in the form of a petiole, propodeum with a short but distinct convex

Date of publication (online): 26 August 2010

Date of publication (print): 26 August 2010

ISSN $0974-7907$ (online) | 0974-7893 (print)

Editor: Hui Xiao

\section{Manuscript details:}

Ms \# 02395

Received 27 January 2010

Final revised received 15 July 2010

Finally accepted 16 July 2010

Citation: Sureshan, P.M. (2010). A new species of Anisopteromalus Ruschka (Hymenoptera: Chalcidoidea: Pteromalidae) from Sri Lanka. Journal of Threatened Taxa 2(9): 1144-1146.

Copyright: (c) P.M. Sureshan 2010. Creative Commons Attribution 3.0 Unported License. JoTT allows unrestricted use of this article in any medium for non-profit purposes, reproduction and distribution by providing adequate credit to the authors and the source of publication.

Acknowledgements: I am grateful to Dr. Ramakrishna, Director Zoological Survey of India, Kolkatta for providing all the facilities for the work and constant encouragement. I am also grateful to Dr. T.C. Narendran, Professor (Emeritus), University of Calicut, Kerala for providing important literature on Anisopteromalus and encouragement. My sincere thanks are also due to Dr. Steven L. Heydon, Bohart Museum of Entomology, University of California, USA for providing the specimens on loan and Dr. John. Noyes and Mrs. Suzanne Ryder, Natural History Museum, U.K. for arranging the loan of the type material of Anisopteromalus deposited there.

\section{OPEN ACCESS | FREE DOWNLOAD}

nucha, median carina and plicae developed only anteriorly and with weak costula.

Six species are known under the genus. A. calandrae (Howard) is widespread (introduced along with the hosts) having a wide range of hosts, mainly of Coleoptera and some Lepidoptera. The species is an important natural enemy of many small beetles associated with stored products and it is reared in commercial insectaries for release in grain bins. The other species known under the genus are A. apiovorus Rasplus (Afrotropical, parasitic on Apionidae (Coleoptera)), A. caryedophagus Rasplus (Afrotropical, parasitic on Bruchidae (Coleoptera)), A. camerunus (Risbec) (Cameroon, parasitic on Cecidomyiidae (Diptera), A. glaber Szelenyi (Germany), and $A$. schwenkei (Roomi, Khan \& Khan) (Pakistan) (Rasplus 1988; Noyes 2003). According to (Bouček et al. 1979) $A$. schwenkei is nothing but $A$. calandrae (Howard) but the synonymy was not confirmed due to the non-availability of the type material for further studies. In continuation of the studies on Pteromalidae of Sri Lanka (Sureshan 2007), an undescribed species of Anisopteromalus was identified. This interesting new species is described hereunder. The specimens of the new species belong to the Bohart Museum of Entomology, University of California, Davis, USA, which are on Ioan to me arranged by the kind courtesy of Dr. Steven L. Heydon.

\section{Anisopteromalus ceylonensis sp. nov. (Figs. 1-6, Photos 1-2)}

\section{Material examined}

Holotype: 25-29.viii.1999, female, Malaise trap, Mahawele R, Rantembe Sanctuary, Vict. Randeinigala, Kandy District, Central Provinces, Sri Lanka, coll. M

Abbreviations: F1-F5 - Funicular segments 1 to 5; MV Marginal vein; OOL - Ocellocular distance; PMV - Post marginal vein; POL - Post ocellar distance; SMV - Submarginal vein; STV - Stigmal vein; T1-T4 - Gastral tergites 1 to 4; UCDC - Bohart Museum of Entomology, University of California, Davis, USA; ZSIP - Zoological Survey of India, Gangetic Plains Regional Centre, Patna. 


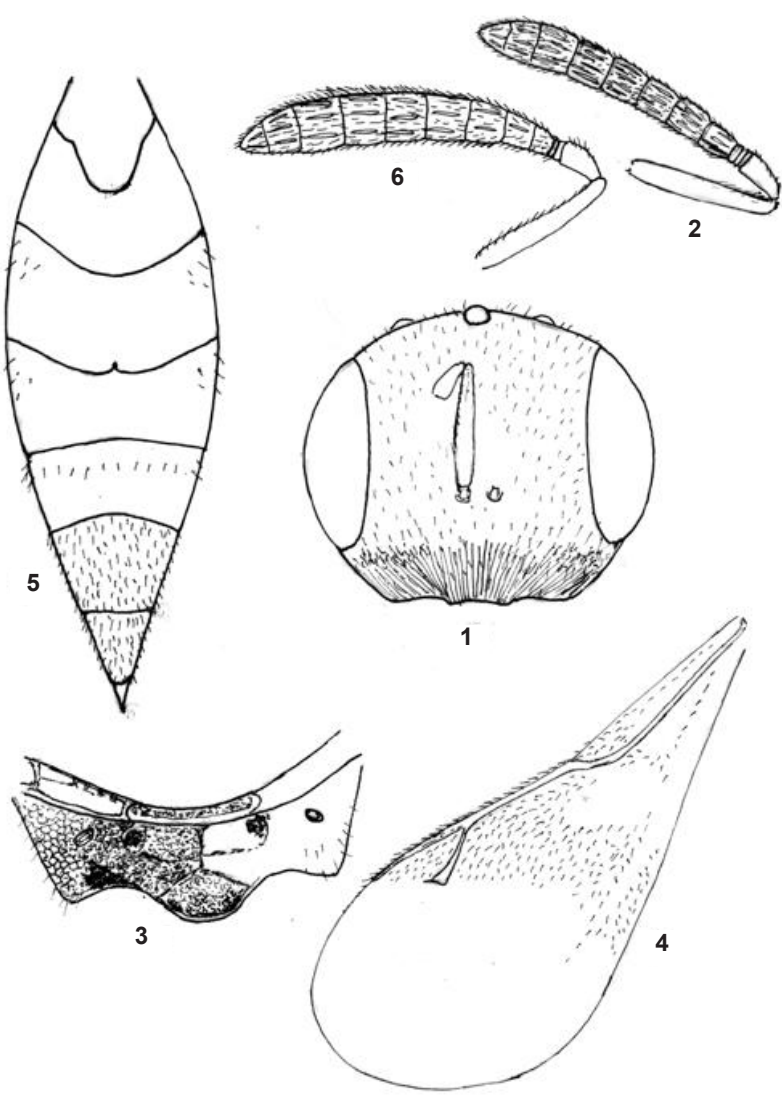

Figures 1-6. Anisopteromalus ceylonensis sp. nov. (Female).

1 - Head in front view; 2 - Antenna; 3 - Propodeum in dorsal view; 4 - Forewing; 5 - Gaster in dorsal view; 6 - Male antenna.

\& J. Wasbauer. Temporarily registered in ZSIP (Reg. No.A.1343) to be registered and deposited in UCDC, the loan depository.

Paratypes: 4 males, data same as that of holotype. Temporarily registered in ZSIP (Reg.No.A.1344) to be registered and deposited in UCDC, the loan depository.

\section{Etymology}

The species name is derived from the old name of the Democratic Republic of Sri Lanka where the specimens were collected.

\section{Description}

Female: Length $2 \mathrm{~mm}$. Head and thorax metallic blue almost blackish. Gaster brown with slight metallic bluish reflection laterally. Legs with coxae concolorous with thorax, remainder of legs yellowish-brown except distal half of tibiae and whole tarsi paler. Eyes cupreous, ocelli silvery white. Antennae uniformly testaceous. Mandibles brown. Tegulae brown, wings hyaline with veins pale brown.

Head: Uniformly reticulate punctures except for fine striate reticulation on genae and closer reticulation on vertex; clypeus striated, striae extending beyond clypeal margin, reaching malar area almost up to base of eyes. Head in dorsal view $2 x$ as broad as long; $P O L$ slightly longer than $2 x$ OOL; temple round, $0.4 x$ eye length in dorsal view. Eye length $1.5 x$ width in profile. Head (Fig. 1) in front view 1.2x as wide as long; malar grooves distinct, malar space $0.6 \mathrm{x}$ eye height. Clypeal margin emarginated in the middle; both mandibles with four teeth; eyes separated 1.4x their height, at the level of toruli; scrobe locally deep. Antennae (Fig. 2) inserted distinctly below middle of face and above the lower ocular line; scape not reaching median ocellus, length $0.7 x$ eye height, pedicel plus flagellum $0.83 x$ as long as breadth of head, pedicel slightly longer than F1, third anellus longer than other two, F1-F4 almost equal in length, F5 slightly shorter, funicular segments with two irregular rows of long sensillae except on F1 in single row, club little longer than two preceding segments combined, sutures oblique, area of micropilosity restricted to the third segment.

Thorax: (Images 1 \& 2) Moderately convex, distinctly reticulate punctures with moderately dense white hairs. Anterior margin of pronotum round, not carinate. Mesoscutum 2x as broad as long, notauli deep, incomplete, reaching beyond middle. Scutellum reticulate punctuate with meshes broad, medially as long as mesoscutum; axillae similarly sculptured as on scutellum. Dorsellum narrow, very finely reticulate. Propodeum (Fig.
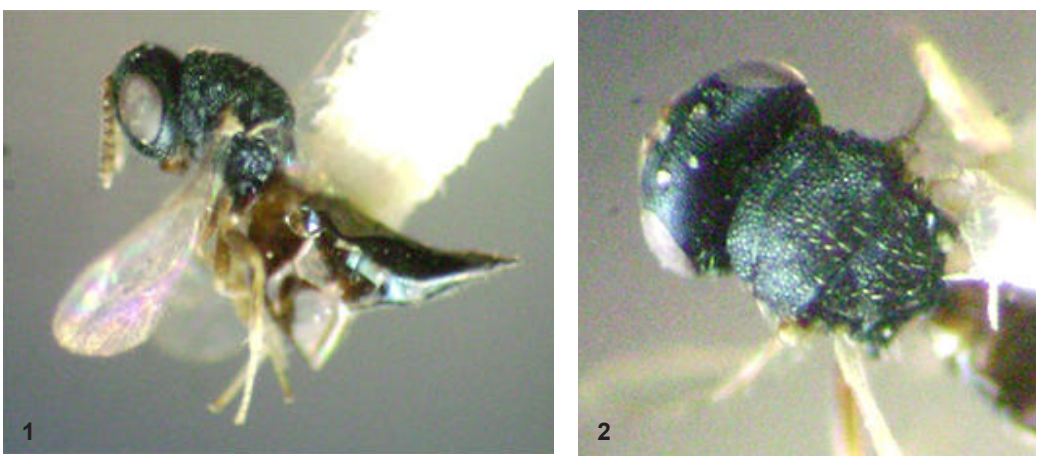

Images 1 \& 2. Anisopteromalus ceylonensis sp. nov.

1 - Female profile view; 2 - Head and thorax dorsal view. 
3) with median area finely reticulate, sides moderately reticulate; median carina fine but distinct, indicated in the anterior half, nuchal area little raised, bordered anteriorly by a very fine transverse ridge; costula finely indicated; plicae indicated only anteriorly, plical sulcus moderately deep; spiracles broad, oval,close to hind margin of metanoutm; callus with few scattered hairs; median area of propodeum, half as long as median length of scutellum, in dorsal view propodeum 3.2x as broad as long. Prepectus triangular, very finely reticulate, almost as long as tegula. Mesopleuron distinctly reticulate punctures except for a triangular shiny area beneath hind wing; metapleuron reticulate punctuate. Legs slender, hind coxa $1.4 \mathrm{x}$ as long as broad, hairy towards posterio-lateral part, hind femur with two unequal spurs. Relative lengths of hind coxa 11, femur 18, tibia 20 and tarsus 18. Forewing (Fig. 4) length $2.03 x$ width, pubescence moderate, marginal fringe small, speculum partly open below, basal hairline indicated, basal cell not hairy, costal cell length $11 x$ width, completely hairy in distal half. Relative lengths of SMV 22, MV 12, PMV 10, STV 5.

Gaster: (Fig. 5) Lanceolate, $1.24 \mathrm{x}$ as long as head plus thorax combined, in dorsal view length $2.6 \mathrm{x}$ width, T1 collapsed to form a basal petiole like structure, hypopygium reaching the end of $\mathrm{T} 4$, hind margin of $\mathrm{T} 1$ and T2 entire, T3 slightly incised.

Male: Length: 1.1-1.4 mm. Differs from female in having smaller body, gaster short compressed and with a broad yellow patch dorsally up to middle, antennae (Fig. 6) more clavate and hairy, with 2 anelli and 6 funicular segments, all transverse, F1 shortest and anelliform, anelli transverse and equal in length.

Biology: Unknown.

\section{Remarks}

This species resembles $A$. caryedophagus Rasplus in general morphology but differs from $A$. caryedophagus with the following characters: body relatively small and slender with coarse reticulation, gaster longer than head and thorax combined, with T1 highly collapsed to form a petiole like structure, propodeum with costula weak, median carina fine but not interrupted beyond the costula, antennae uniformly testaceous with F1 slightly shorter than pedicel and flagellum more clavate, fore wing with costal cell length $11 \mathrm{x}$ width, MV 2.4x STV, PMV long, almost $2 x$ STV, basal cell with no hairs. The new species also same with $A$. calandrae. The latter species differs from the new species in having a stout body with finer sculpture and dense pubescence, antennae uniformly brown; gaster shorter than head and thorax combined, POL 1.3x OOL, fore wing with MV short, 1.3x STV,PMV little longer than MV, basal cell with few hairs and antenna less broad towards tip with $\mathrm{F} 1$ as long as pedicel.

\section{REFERENCES}

Bouček, Z., B.R.S. Rao \& S.I. Farooqi (1979). A preliminary review of Pteromalidae (Hymenoptera) of India and adjacent countries. Oriental Insects 12(4): 433-467

Noyes, J.S. (2003). Universal Chalcidoidea Database. http://www. nhm.ac.ukjdsml/research-curation/projects/chalcidoids. Last updated April 2009. Accessed on 26 November 2009.

Rasplus, J.Y. (1988). Description de deux nouvelles especes du genre Anisopteromalus Rutschka Cle des especes afrotropicales (Hym. Pteromalidae). Bulletin de la Societe Entomologique de France. 93(3-4): 123-125.

Sureshan, P.M. (2007). Taxonomic studies on Pteromalidae (Hymenoptera: Chalcidoidea) of Southeast Asia based on collections of Bohart Museum of Entomology, University of California, Davis, USA. Records of Zoological Survey of India. Occasional paper (268): 1-42. 